\title{
The use of MELD scores in critically ill cirrhotic patients
}

\author{
Supannee Rassameehiran MD, Tinsay A. Woreta MD MPH
}

\begin{abstract}
The Model for End-Stage Liver Disease (MELD) was originally created to predict survival following transjugular intrahepatic portosystemic shunt and was subsequently found to accurately predict mortality in patients with end-stage liver disease. It has been used in the United States for liver allocation since 2002, and implementation of the MELD score resulted in a reduction in total number of deaths on the waitlist and a reduction in waiting time. Critically ill cirrhotic patients have an in-hospital mortality greater than $50 \%$. Although the MELD score was also found to be an accurate predictor of in-ICU mortality and in-hospital mortality after ICU admission in critically ill cirrhotic patients, the Sequential Organ Failure Assessment (SOFA) score appears to perform better in many studies. The Chronic Liver Failure Consortium Acute-onChronic Liver Failure (CLIF-C ACLF) score was later developed by using specific cut-points for each organ failure score system in CLIF patients to predict mortality in patients with ACLF. Neither the MELD nor SOFA score independently predicts post-liver transplantation mortality in cirrhotic patients with extrahepatic organ failure and should not be use as a delisting criterion for these patients. More data are needed to determine the accuracy of the CLIF-C ACLF score in predicting post-liver transplantation outcomes. Prospective evaluation of critically ill cirrhotic patients is needed to optimize liver organ allocation.
\end{abstract}

Key words-Cirrhosis, MELD score, SOFA score

\section{INTRODUCTION}

The Model for End-Stage Liver Disease (MELD) is a numerical scale, ranging from 6 to 40 , that was originally created to predict survival following transjugular intrahepatic portosystemic shunt (TIPS) for refractory variceal bleeding or refractory ascites. ${ }^{1}$ The score is calculated by a formula using serum bilirubin, serum creatinine, and the International Normalized Ratio (INR). It was later adopted by the United Network for Organ Sharing (UNOS) to determine priority for liver organ allocation in the United States in February $2002 .^{2}$ The MELD score predicts liver transplantation (LT) waitlist mortality with estimated three-month mortality of $4 \%, 27 \%$, $76 \%, 83 \%$, and $100 \%$ for MELD scores of $<10,10-19,20-29,30-39$, and $\geq 40$, respectively. ${ }^{3}$ Implementation of the MELD score for organ allocation resulted in a reduction in total number of deaths on the waitlist and a reduction in waiting time. ${ }^{4}$ In January 2016, the MELD-Na score was implemented for LT allocation, as hyponatremia also strongly predicts mortality in these patients. ${ }^{5-}$ 7 Apart from prioritizing the urgency for LT, the

Corresponding author- Supannee Rassameehiran Contact: Information: s.rassameehiran@gmail.com DOI: $10.12746 /$ swrccc2016.0416.219
MELD score accurately predicts outcomes in cirrhotic patients with infection ${ }^{8-10}$, variceal bleeding $^{11,12}$, trauma ${ }^{13}$, and surgery other than $\mathrm{LT}$, including liver resection. ${ }^{14,15}$ It is also used as one of the liver-specific prognosis scores for critically ill cirrhotic patients in the intensive care unit (ICU).

\section{Prognostic scoring systems for critically ill cirrhotic patients in ICU}

Liver cirrhosis is the $12^{\text {th }}$ leading cause of death in the United States. ${ }^{16}$ The prevalence of liver cirrhosis is increasing and is estimated to be present in approximately 630,000 adults in the United States. ${ }^{17}$ Cirrhotic patients are at an increased risk for developing decompensation related to cirrhosis and portal hypertension, including variceal bleeding, ascites, hepatic encephalopathy, hepato-renal syndrome, spontaneous bacterial peritonitis, and sepsis. Patients with cirrhosis admitted to the ICU have a substantially high mortality rate of $50 \%$ to $100 \%$. ${ }^{18}$ Liver-specific prognosis scores [Child-TurcottePugh (CTP) and MELD] and ICU-specific prognosis scores [Simplified Acute Physiology 
Score (SAPS) II, Acute Physiology and Chronic Health Evaluation (APACHE), and Sequential Organ Failure Assessment (SOFA)] have been proposed to assess disease severity and outcomes in these patients.

\section{MELD score as a prognostic predictor for cirrhotic patients in ICU}

The MELD score is calculated by the formula $3.8 * \log _{\mathrm{e}}($ serum bilirubin $[\mathrm{mg} / \mathrm{dL}])+$ $11.2 * \log _{\mathrm{e}}(\mathrm{INR})+9.6 * \log _{\mathrm{e}}($ serum creatinine $[\mathrm{mg} / \mathrm{dL}])+6.4$. It contains only objective values that eliminate intra-and inter-observer variability. Unfortunately, other than renal dysfunction, the MELD score does not directly account for other complications of portal hypertension, such as ascites, variceal bleeding, hepatic encephalopathy, hepatopulmonary syndrome, portopulmonary hypertension, and cirrhotic cardiomyopathy. Thus patients with significant decompensation from complications of portal hypertension may have low MELD scores that do not accurately reflect the severity of their liver disease and are at a disadvantage with our current method of organ allocation using the MELD score. A system of exception points has been implemented for those patients with complications of portal hypertension that are not captured by the MELD score, such as hepatopulmonary syndrome and portopulmonary hypertension, to increase their waitlist priority. The MELD score can also be influenced by acute illnesses that alter bilirubin, creatinine, or INR values (Table 1).

The main cause of death in cirrhotic patients in the ICU is multisystem organ failure. ${ }^{26}$ Several studies have shown that besides hepatic failure, cardiovascular system dysfunction ${ }^{27,28}$, renal failure ${ }^{21,} 29$, elevated lactate ${ }^{30-32}$, and ascites $^{32}$ were independent factors for mortality. Unlike the MELD score which focuses only on hepatic and renal function, ICU-specific prognosis scores also consider other organ system dysfunction (Table 2).

\section{Comparing MELD score and ICU-specific scores (SAPS II, APACHE II, SOFA)}

Many studies have compared MELD scores with ICU-specific prognosis scores in predicting in-ICU mortality and in-hospital mortality for cirrhotic patients after ICU admission. Most studies have shown that SOFA scores correlate with mortality better than MELD scores $^{31-38}$, APACHE II scores ${ }^{31,32,34,38-41}$, and SAPS II scores. ${ }^{37}$ Das et al reported the presence of five non-hematologic organ failures in the SOFA score at the admission to the ICU was associated with $100 \%$ in-hospital mortality. ${ }^{33}$ Moreover, the accuracy of SOFA scores was improved when reassessed at 48 to 72 hours after the admission to the ICU. ${ }^{18,}{ }^{38}$ However, Boone et al reported that both SOFA scores and MELD scores did not perform well in predicting 28-day mortality in the surgical ICU patients. ${ }^{42}$

Each of the six different organ failures in the SOFA score has a different weight in cirrhotic patients. ${ }^{43}$ Hematologic failure in SOFA score defined by platelet count $\leq 50 \mathrm{k} / \mu \mathrm{L}$ has no impact on the prognosis in cirrhotic patients ${ }^{33}$ New cut-off values for SOFA scores dedicated to cirrhotic patients were proposed resulting in a development of new scoring systems: the Chronic Liver Failure-SOFA (CLIF-SOFA) score and the Chronic Liver Failure Consortium Acute-onChronic Liver Failure (CLIF-C ACLF) score.

The CLIF-C ACLF score was specifically developed using data from patients with the diagnosis of ACLF, which was defined as an acute deterioration in liver function in an individual with pre-existing chronic liver disease and hepatic and extrahepatic organ failures. ${ }^{44}$ Validation of the score was confirmed with external single center prospective cohort study of ACLF patients admitted to the ICU. ${ }^{37}$ Jalan et al reported that CLIF-C ACLF score correlates with mortality better than the MELD score, MELD-Na score, CTP score, and CLIF-SOFA score in patients with ACLF. ${ }^{44}$ Sequential use of the score also improves the predictive performance and should be considered as a good prognostic predictor for cirrhotic patients. ${ }^{44}$

Evidence for the MELD score, SOFA score, and CLIF-C ACLF score predicting post-LT outcome is lacking. A systematic review by Cholongitas et al found that the MELD score does not predict post-LT mortality. ${ }^{45} \mathrm{~A}$ recent study by Karvellas et al reported that the SOFA score was not associated with an increased risk of 90-day post-LT mortality. ${ }^{46}$ Optimal organ allocation in cirrhotic patients with extrahepatic organ failure should be prospectively evaluated.

\section{Conclusion}

The MELD score predicts liver transplantation waitlist mortality and has been used in the United States for liver allocation since 2002. Prior studies have compared the MELD score with ICU-specific prognosis scores in predicting in-ICU mortality and in-hospital mortality of cirrhotic patients after ICU admission. 
Although the MELD score was found to be an accurate predictor of mortality in critically ill cirrhotic patients, the CLIF-C ACLF score correlates with mortality better than the MELD score, MELD-Na score, CTP score, and CLIF-
SOFA score in patients with ACLF. Thus we recommend the CLIF-C ACLF score as a prognostic predictor for patients with acute-onchronic liver

failure. 
Table 1 Influencing factors of MELD score

\begin{tabular}{|c|c|}
\hline Variable & Influencing factors \\
\hline Bilirubin & $\begin{array}{l}\text { Increased indirect bilirubin } \\
\quad \text { Hemolysis } \\
\text { Blood transfusion } \\
\text { Drug or sepsis-induced cholestasis }{ }^{19,20}\end{array}$ \\
\hline Creatinine & $\begin{array}{l}\text { Acute renal failure } \\
\text { Hepatorenal syndrome } \\
\text { Other causes: shock, hypovolemia, drug- } \\
\text { induced nephropathy, and medication- } \\
\text { induced nephropathy }\end{array}$ \\
\hline INR & $\begin{array}{l}\text { Anticoagulant therapy: warfarin } \\
\text { Hemodilution }^{23} \\
\text { Bleeding-induced coagulopathy }^{24} \\
\text { Disseminated intravascular coagulopathy } \\
\text { Malnutrition }\end{array}$ \\
\hline
\end{tabular}

INR- International Normalized Ratio

Table 2 Components of ICU-specific prognosis scores

\begin{tabular}{|c|c|}
\hline Organ system & ICU-specific prognosis scores \\
\hline $\begin{array}{c}\text { Cardiovascular system } \\
\text { Heart rate } \\
\text { Blood pressure }\end{array}$ & $\begin{array}{l}\text { SAPS II, APACHE II } \\
\text { SAPS II, APACHE II, SOFA }\end{array}$ \\
\hline $\begin{array}{l}\text { Respiratory system } \\
\text { Respiratory rate } \\
\mathrm{PaO} 2 \text { or } \mathrm{PaO} 2 / \mathrm{FiO} 2\end{array}$ & $\begin{array}{l}\text { APACHE II } \\
\text { SAPS II, APACHE II, SOFA }\end{array}$ \\
\hline $\begin{array}{l}\text { Renal function } \\
\text { Serum creatinine } \\
\text { Serum urea } \\
\text { Oliguria }\end{array}$ & $\begin{array}{l}\text { APACHE II (acute renal failure) } \\
\text { SOFA, APACHE II } \\
\text { SAPS II } \\
\text { SAPS II, SOFA }\end{array}$ \\
\hline $\begin{array}{r}\text { Liver function } \\
\text { Bilirubin }\end{array}$ & $\begin{array}{l}\text { APACHE II (cirrhosis) } \\
\text { SAPS II, SOFA }\end{array}$ \\
\hline $\begin{array}{c}\text { Hematologic findings } \\
\text { WBC count } \\
\text { Platelet }\end{array}$ & $\begin{array}{l}\text { SAPS II, APACHE II } \\
\text { SOFA }\end{array}$ \\
\hline $\begin{array}{l}\text { Neurologic function } \\
\text { Consciousness }\end{array}$ & SAPS II, APACHE II, SOFA \\
\hline
\end{tabular}

SAPS- Simplified Acute Physiology Score; APACHE- Acute Physiology and Chronic Health Evaluation;

SOFA-Sequential Organ Failure Assessment 


\section{REFERENCES}

1. Malinchoc M, Kamath PS, Gordon FD, Peine CJ, Rank J, ter Borg PC. A model to predict poor survival in patients undergoing transjugular intrahepatic portosystemic shunts. Hepatology 2000;31(4):864-871.

2. Wiesner R, Edwards E, Freeman R, Harper A, Kim R, Kamath P, Kremers W, Lake J, Howard T, Merion RM, Wolfe RA, Krom R, United Network for Organ Sharing Liver Disease Severity Score C. Model for end-stage liver disease (MELD) and allocation of donor livers.

Gastroenterology 2003;124(1):91-96.

3. Singal AK, Kamath PS. Model for End-stage Liver Disease. J Clin Exp Hepatol 2013;3(1):50-60.

4. Wiesner R, Lake JR, Freeman RB, Gish RG. Model for end-stage liver disease (MELD) exception guidelines. Liver Transpl 2006;12(12 Suppl 3):S85-87.

5. Heuman DM, Abou-Assi SG, Habib A, Williams LM, Stravitz RT, Sanyal AJ, Fisher RA, Mihas AA. Persistent ascites and low serum sodium identify patients with cirrhosis and low MELD scores who are at high risk for early death. Hepatology 2004;40(4):802-810.

6. Biggins SW, Rodriguez HJ, Bacchetti P, Bass NM, Roberts JP, Terrault NA. Serum sodium predicts mortality in patients listed for liver transplantation. Hepatology 2005;41(1):32-39.

7. Kalra A, Wedd JP, Biggins SW. Changing prioritization for transplantation: MELD-Na, hepatocellular carcinoma exceptions, and more. Curr Opin Organ Transplant 2016;21(2):120-126.

8. Kraja B, Sina M, Mone I, Pupuleku F, Babameto A, Prifti S, Burazeri G. Predictive Value of the Model of End-Stage Liver Disease in Cirrhotic Patients with and without Spontaneous Bacterial Peritonitis. Gastroenterol Res Pract 2012;2012539059.

9. Viasus D, Garcia-Vidal C, Castellote J, Adamuz J, Verdaguer R, Dorca J, Manresa F, Gudiol F, Carratala J. Community-acquired pneumonia in patients with liver cirrhosis: clinical features, outcomes, and usefulness of severity scores. Medicine (Baltimore) 2011;90(2):110-118. 10. Obstein KL, Campbell MS, Reddy KR, Yang YX. Association between model for end-stage liver disease and spontaneous bacterial peritonitis. Am J Gastroenterol 2007;102(12):2732-2736.

11. Chalasani N, Kahi C, Francois F, Pinto A, Marathe A, Bini EJ, Pandya P, Sitaraman S, Shen J. Model for end-stage liver disease (MELD) for predicting mortality in patients with acute variceal bleeding. Hepatology 2002;35(5):12821284.

12. Bambha K, Kim WR, Pedersen R, Bida JP, Kremers WK, Kamath PS. Predictors of early re-bleeding and mortality after acute variceal haemorrhage in patients with cirrhosis. Gut 2008;57(6):814-820.

13. Inaba K, Barmparas G, Resnick S, Browder T, Chan LS, Lam L, Talving P, Demetriades D. The Model for EndStage Liver Disease score: an independent prognostic factor of mortality in injured cirrhotic patients. Arch Surg 2011;146(9):1074-1078.

14. Teh SH, Sheppard BC, Schwartz J, Orloff SL. Model for End-stage Liver Disease score fails to predict perioperative outcome after hepatic resection for hepatocellular carcinoma in patients without cirrhosis. Am J Surg 2008;195(5):697701.

15. Causey MW, Steele SR, Farris Z, Lyle DS, Beitler AL. An assessment of different scoring systems in cirrhotic patients undergoing nontransplant surgery. Am J Surg 2012;203(5):589-593.

16. Neff GW, Duncan CW, Schiff ER. The current economic burden of cirrhosis. Gastroenterol Hepatol (N Y) 2011;7(10):661-671.

17. Scaglione S, Kliethermes S, Cao G, Shoham D, Durazo R, Luke A, Volk ML. The Epidemiology of Cirrhosis in the United States: A Population-based Study. J Clin Gastroenterol 2015;49(8):690-696.

18. Frohlich S, Murphy N, Kong T, Ffrench-O'Carroll R, Conlon N, Ryan D, Boylan JF. Alcoholic liver disease in the intensive care unit: outcomes and predictors of prognosis. $J$ Crit Care 2014;29(6):1131 e1137-1131 e1113.

19. Chand N, Sanyal AJ. Sepsis-induced cholestasis.

Hepatology 2007;45(1):230-241.

20. Frenette AJ, Dufresne ME, Bonhomme V, Albert M, Williamson DR. Drug-induced hepatic cholestasis in the critically ill. Intensive Care Med 2011;37(7):1225-1226. 21. du Cheyron D, Bouchet B, Parienti JJ, Ramakers M, Charbonneau P. The attributable mortality of acute renal failure in critically ill patients with liver cirrhosis. Intensive Care Med 2005;31(12):1693-1699.

22. Belcher JM, Garcia-Tsao G, Sanyal AJ, Bhogal H, Lim JK, Ansari N, Coca SG, Parikh CR, Consortium T-A. Association of AKI with mortality and complications in hospitalized patients with cirrhosis. Hepatology 2013;57(2):753-762.

23. Sihler KC, Napolitano LM. Complications of massive transfusion. Chest 2010;137(1):209-220.

24. Bosch J, Thabut D, Albillos A, Carbonell N, Spicak J, Massard J, D'Amico G, Lebrec D, de Franchis R, Fabricius S, Cai Y, Bendtsen F, International Study Group on $\mathrm{r}$ FiUGIH. Recombinant factor VIIa for variceal bleeding in patients with advanced cirrhosis: A randomized, controlled trial. Hepatology 2008;47(5):1604-1614.

25. Takemitsu T, Wada H, Hatada T, Ohmori Y, Ishikura K, Takeda T, Sugiyama T, Yamada N, Maruyama K, Katayama $\mathrm{N}$, Isaji S, Shimpo H, Kusunoki M, Nobori T. Prospective evaluation of three different diagnostic criteria for disseminated intravascular coagulation. Thromb Haemost 2011;105(1):40-44.

26. Zauner CA, Apsner RC, Kranz A, Kramer L, Madl C, Schneider B, Schneeweiss B, Ratheiser K, Stockenhuber F, Lenz K. Outcome prediction for patients with cirrhosis of the liver in a medical ICU: a comparison of the APACHE scores and liver-specific scoringsystems. Intensive Care Med 1996;22(6):559-563.

27. Tsai MH, Chen YC, Ho YP, Fang JT, Lien JM, Chiu CT, Liu NJ, Chen PC. Organ system failure scoring system can predict hospital mortality in critically ill cirrhotic patients. J Clin Gastroenterol 2003;37(3):251-257.

28. Tsai MH, Peng YS, Lien JM, Weng HH, Ho YP, Yang C, Chu YY, Chen YC, Fang JT, Chiu CT, Chen PC. Multiple organ system failure in critically ill cirrhotic 
patients. A comparison of two multiple organ dysfunction/failure scoring systems. Digestion 2004;69(3):190-200.

29. Arabi Y, Ahmed QA, Haddad S, Aljumah A, AlShimemeri A. Outcome predictors of cirrhosis patients admitted to the intensive care unit. Eur J Gastroenterol Hepatol 2004;16(3):333-339.

30. Zauner C, Schneeweiss B, Schneider B, Madl C, Klos H, Kranz A, Ratheiser K, Kramer L, Lenz K. Short-term prognosis in critically ill patients with liver cirrhosis: an evaluation of a new scoring system. Eur J Gastroenterol Hepatol 2000;12(5):517-522.

31. Cholongitas E, Senzolo M, Patch D, Kwong K, Nikolopoulou V, Leandro G, Shaw S, Burroughs AK. Risk factors, sequential organ failure assessment and model for end-stage liver disease scores for predicting short term mortality in cirrhotic patients admitted to intensive care unit. Aliment Pharmacol Ther 2006;23(7):883-893.

32. Emerson P, McPeake J, O'Neill A, Gilmour H, Forrest E, Puxty A, Kinsella J, Shaw M. The utility of scoring systems in critically ill cirrhotic patients admitted to a general intensive care unit. J Crit Care 2014;29(6):1131 e1131-1136.

33. Das V, Boelle PY, Galbois A, Guidet B, Maury E, Carbonell N, Moreau R, Offenstadt G. Cirrhotic patients in the medical intensive care unit: early prognosis and longterm survival. Crit Care Med 2010;38(11):2108-2116. 34. Cholongitas E, Betrosian A, Senzolo M, Shaw S, Patch D, Manousou P, O'Beirne J, Burroughs AK. Prognostic models in cirrhotics admitted to intensive care units better predict outcome when assessed at $48 \mathrm{~h}$ after admission. $J$ Gastroenterol Hepatol 2008;23(8 Pt 1):1223-1227. 35. Filloux B, Chagneau-Derrode C, Ragot S, Voultoury J, Beauchant M, Silvain C, Robert R. Short-term and longterm vital outcomes of cirrhotic patients admitted to an intensive care unit. Eur J Gastroenterol Hepatol 2010;22(12):1474-1480.

36. Tu KH, Jenq CC, Tsai MH, Hsu HH, Chang MY, Tian YC, Hung CC, Fang JT, Yang CW, Chen YC. Outcome scoring systems for short-term prognosis in critically ill cirrhotic patients. Shock 2011;36(5):445-450.

37. Levesque E, Hoti E, Azoulay D, Ichai P, Habouchi H, Castaing D, Samuel D, Saliba F. Prospective evaluation of the prognostic scores for cirrhotic patients admitted to an intensive care unit. J Hepatol 2012;56(1):95-102.

38. Cholongitas E, Agarwal B, Antoniadis N, Burroughs AK. Patients with cirrhosis admitted to an intensive care unit. J Hepatol 2012;57(1):230-231; author reply 231-232. 39. Juneja D, Gopal PB, Kapoor D, Raya R,

Sathyanarayanan M, Malhotra P. Outcome of patients with liver cirrhosis admitted to a specialty liver intensive care unit in India. J Crit Care 2009;24(3):387-393.

40. Wehler M, Kokoska J, Reulbach U, Hahn EG, Strauss R. Short-term prognosis in critically ill patients with cirrhosis assessed by prognostic scoring systems. Hepatology 2001;34(2):255-261.

41. Chen YC, Tian YC, Liu NJ, Ho YP, Yang C, Chu YY, Chen PC, Fang JT, Hsu CW, Yang CW, Tsai MH.

Prospective cohort study comparing sequential organ failure assessment and acute physiology, age, chronic health evaluation III scoring systems for hospital mortality prediction in critically ill cirrhotic patients. Int J Clin Pract 2006;60(2):160-166.

42. Boone MD, Celi LA, Ho BG, Pencina M, Curry MP, Lior Y, Talmor D, Novack V. Model for End-Stage Liver Disease score predicts mortality in critically ill cirrhotic patients. J Crit Care 2014;29(5):881 e887-813.

43. Galbois A, Das V, Carbonell N, Guidet B. Prognostic scores for cirrhotic patients admitted to an intensive care unit: which consequences for liver transplantation? Clin Res Hepatol Gastroenterol 2013;37(5):455-466.

44. Jalan R, Saliba F, Pavesi M, Amoros A, Moreau R, Gines P, Levesque E, Durand F, Angeli P, Caraceni P, Hopf C, Alessandria C, Rodriguez E, Solis-Munoz P, Laleman W, Trebicka J, Zeuzem S, Gustot T, Mookerjee R, Elkrief L, Soriano G, Cordoba J, Morando F, Gerbes A, Agarwal B, Samuel D, Bernardi M, Arroyo V, Consortium CsiotE-C. Development and validation of a prognostic score to predict mortality in patients with acute-on-chronic liver failure. $J$ Hepatol 2014;61(5):1038-1047.

45. Cholongitas E, Marelli L, Shusang V, Senzolo M, Rolles $\mathrm{K}$, Patch D, Burroughs AK. A systematic review of the performance of the model for end-stage liver disease (MELD) in the setting of liver transplantation. Liver Transpl 2006;12(7):1049-1061.

46. Karvellas CJ, Lescot T, Goldberg P, Sharpe MD, Ronco JJ, Renner EL, Vahidy H, Poonja Z, Chaudhury P, Kneteman NM, Selzner M, Cook EF, Bagshaw SM, Canadian Liver Failure Study G. Liver transplantation in the critically ill: a multicenter Canadian retrospective cohort study. Crit Care 2013;17(1):R28.

\section{DETAILS}

1.Submitted-4/4/2016

2. Accepted-9/23/2016

3. Reviewer-Thomas Kerr MD

4. Author affiliation- Supannee Rassameehiran was a resident in Internal Medicine at Texas Tech University Health Sciences Center in Lubbock, TX. Tinsay A. Woreta was a transplant hepatologist working at TTUHSC in Lubbock, TX.

5. Corresponding author- Supannee Rassameehiran at s.rassameehiran@gmail.com

6. Conflicts-none 